\title{
Accumulation of domoic acid in marine organisms from Sriracha bay, Chonburi province, Thailand
}

\author{
Oning Veschasit ${ }^{\mathrm{a}}$, Shettapong Meksumpun ${ }^{\mathrm{a}, \mathrm{b}, \mathrm{c}, *}$, Nissara Thawonsode ${ }^{\mathrm{a}}$, \\ Thaithaworn Lirdwitayaprasit ${ }^{\mathrm{d}}$ \\ ${ }^{a}$ Department of Marine Science, Faculty of Fisheries, Kasetsart University, Bangkok 10900 Thailand \\ b Centre for Advanced Studies in Tropical Natural Resources, \\ National Research University-Kasetsart University, Kasetsart University, \\ Bangkok 10900 Thailand (CASTNAR, NRU-KU, Thailand) \\ c Centre for Advanced Studies for Agriculture and Food, \\ National Research University-Kasetsart University, Kasetsart University, \\ Bangkok 10900 Thailand (CASAF, NRU-KU, Thailand) \\ d Department of Marine Science, Faculty of Science, Chulalongkorn University, Bangkok 10330 Thailand
}

*Corresponding author, e-mail: ffisspm@ku.ac.th

\begin{abstract}
Domoic acid (DA), a toxin produced by diatoms Pseudo-nitzschia and Nitzschia, causes amnesic shellfish poisoning. DA accumulated in marine organisms from Sriracha bay, Chonburi province, Thailand was determined from May 2012 to July 2013. Field surveys and sample collections were conducted every two months. DA content was determined using the enzyme linked immunosorbent assay (ELISA) method and ranged between not detectable and $110 \mathrm{ng} / \mathrm{l}$ for plankton. DA content in zooplankton ranged between 0.04 and $0.21 \mathrm{ng} / \mathrm{l}$ and in Perna viridis, Crassostrea lugubris, and Pinctada fucata it ranged between 214 and 454, 171 and 371, and 117 and $282 \mathrm{ng} / \mathrm{g}$, respectively. DA content in Secutor megalolepis ranged between not detectable and $44.2 \mathrm{ng} / \mathrm{g}$. DA was found in zooplankton, shellfish, and fish from Sriracha bay throughout the year. The amount of DA accumulation in marine organisms was lower than the regulation level $(20 \mu \mathrm{g} / \mathrm{g})$. Average DA content in zooplankton, shellfish, and fish throughout the year were $42 \%$, $44 \%$, and $5 \%$ of the DA content in phytoplankton, respectively. DA transfers from phytoplankton to zooplankton and shellfish were $7 \%$ and $8 \%$, respectively, while transfer from zooplankton to fish was $2 \%$.
\end{abstract}

KEYWORDS: phytoplankton, shellfish, seafood, zooplankton

\section{INTRODUCTION}

Currently, food safety is a hot global issue. Increasing reports concerning toxic phytoplankton blooms in many coastal areas have increased the awareness of stakeholders regarding food safety and the method to determine the causes of harmful algal blooms. Seafood contamination by algae is an important issue for the shellfish industry. Biotoxin outbreaks in marine, estuarine and riverine environments usually coincide with phytoplankton blooms. Food poisoning caused by the consumption of fish or shellfish that feed on phycotoxins are divided into six types depending on their exerted effects: paralytic shellfish poisoning, neurotoxic shellfish poisoning, amnesic shellfish poisoning, diarrhoetic shellfish poisoning, azaspiracid poisoning, and ciguatera fish poisoning ${ }^{1,2}$.

Domoic acid (DA) is a neurotoxin that is nat- urally produced by several species of phytoplankton, predominantly of the diatom genus Pseudonitzschia and Nitzschia. This toxin is responsible for a human illness known as amnesic shellfish poisoning (ASP) which enters food webs through feeding interactions and can accumulate in higher trophic levels ${ }^{3}$. DA is a water-soluble, crystalline, non-protein amino acid with a molecular weight of $311 \mathrm{Da}$. It contains a proline ring, one imino group, and three carboxyl groups. The carboxyl groups are responsible for the high hydrophilicity and polarity of the molecule ${ }^{4}$. The chemical structure of DA is similar to another neurotoxin, kainic acid, and to glutamic acid.

In 1958, DA was identified for the first time in the marine red alga (Chondria armata) which also proved to be a source of isodomoic acids $\mathrm{A}$ to $\mathrm{D}^{5}$. Two new isodomoic acids, $\mathrm{E}$ and $\mathrm{F}$, were isolated from the mussel Mytilus edulis in 1990 
and a re-check of C. armata gave two further isodomoic acids, namely $\mathrm{G}$ and $\mathrm{H}^{5}$. Isodomoic acid is also found in plankton cells and shellfish, and is produced by the decomposition of DA when exposed to UV radiation or heat. The first occurrence of ASP occurred in 1987 on the eastern coast of Prince Edward Island, Canada when 143 people became ill and 4 people died after consuming blue mussels ( $M$. edulis) contaminated with DA from the marine diatom Pseudo-nitzschia multiseries $^{6}$. In humans, symptoms of ASP include both gastrointestinal (vomiting and diarrhoea) and neurological effects (short-term memory loss, confusion, seizures, coma, and even death) ${ }^{6}$. Since the incident in Canada, DA has been found in 21 species of diatom as follows: Pseudo-nitzschia australis, P. brasiliana, $P$. caciantha, P. calliantha, $P$. cuspidata, $P$. delicatissima, $P$. fraudulenta, $P$. fukuyoi, $P$ galaxiae, $P$. cf. granii, $P$. kodamae, $P$. multiseries, $P$. multistriata, P. plurisecta, P. pseudodelicatissima, $P$. pungens, $P$ seriata, P. subpacifica, P. turgidula, Nitzschia bizertensis, and N. navis-varingica ${ }^{1}$. Accumulation of DA in bivalves was also reported from various parts of the world ${ }^{7}$. Furthermore, planktivorous fish were found to contain high levels of DA during toxic Pseudo-nitzschia blooms ${ }^{8}$.

The presence or absence of DA contamination in food webs neither reflects the population size of Pseudo-nitzschia, nor the production of DA, since there is still limited understanding of the environmental and oceanographic conditions that stimulate DA production. Thus cells of Pseudo-nitzschia may be present at concentrations of DA too low to contaminate planktivores. Furthermore, although DA depuration of mussels and fish is normally fairly rapid, it cannot completely eliminate the possibility that wide-ranging fish, birds, or mammals obtain the toxin elsewhere ${ }^{9}$.

In nature, material transfer of both energy and nutrients among the trophic levels by eating is the most important basic process ${ }^{10,11}$. However, not only energy and nutrients are passed along the food chain, but also other substances including DDT, mercury, and cadmium. These toxic substances are not used to generate energy for the cell; they accumulate in the body, increasing the concentration of organisms more than those transmitted to the next step by eating (biomagnification). Many scientific studies confirmed that shellfish and fish are good models to evaluate the toxicity in aquatic system due to their ability to metabolize xenobiotics, their sensitivity to pollutants ${ }^{12-15}$ and the position into the aquatic food chain ${ }^{16,17}$. The toxin concentration will reach the highest value in the body of the top consumer $^{18}$.

In Thailand, DA was detected for the first time in Spondylus versicolor at very low concentration ${ }^{19}$. The standard level for DA in shellfish (originally set in Canada) is $20 \mu \mathrm{g} / \mathrm{g}$ DA shellfish tissue ${ }^{20}$. From the toxicity perspective, a harmful level for the California food web was considered to be $5 \times 10^{4}$ cells/1 $P$. australis. At this phytoplankton density, the toxicity from mussels and fish can reach the average toxic levels that have impact on human health ${ }^{8}$. Recently, DA contamination has become more widespread, accompanied by increasing frequency of toxic Pseudo-nitzschia blooms. McCarron and $\mathrm{Hess}^{21}$ found that cooking shellfish products at $121^{\circ} \mathrm{C}$ did not reduce the absolute concentration of DA.

This is the first report of DA accumulation in zooplankton copepods and fish from Thai waters, in which DA was detected in phytoplankton, zooplankton, shellfish, and fish in Sriracha bay, Chonburi Province.

\section{MATERIALS AND METHODS}

\section{Field survey and sample collection}

The study area was located at Sriracha bay, Chonburi province, Thailand (Fig. 1). Field surveys and sample collections were conducted bimonthly from May 2012 to July 2013. May 2012, January, March, and May 2013 were representative of the dry season and July, September, November 2012, and July 2013 comprised the wet season.

Shellfish and fish samples were collected in set nets at about four to ten specimens each. Shellfish specimens included three species as black-scar oyster (C. lugubris), pearl oyster ( $P$. fucata), and Asian green mussel (Perna viridis), while fish specimens

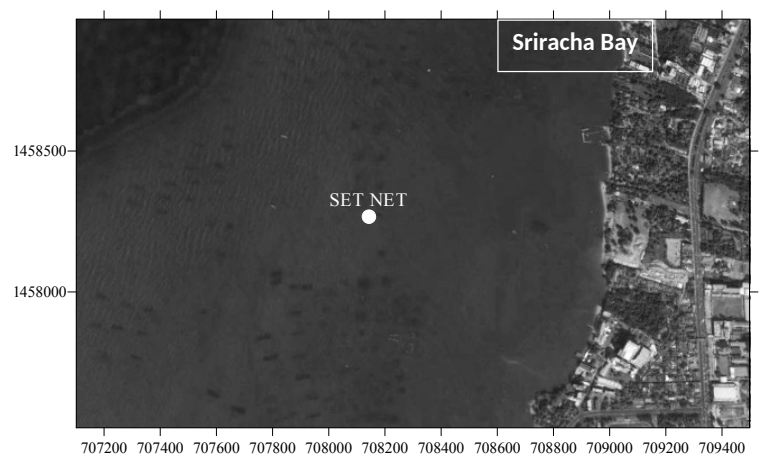

Fig. 1 Map of sampling sites in Sriracha bay, Chonburi province, Thailand. 
included bigscale ponyfish (S. megalolepis). Both shellfish and fish were frozen immediately after collection. Phytoplankton were obtained from 201 of seawater, sampled at $0.5 \mathrm{~m}$ from the surface and $0.5 \mathrm{~m}$ above the sediment. The seawater was filtered through 150 and $5 \mu \mathrm{m}$ plankton nets to collect both small phytoplankton $(<5 \mu \mathrm{m})$ and large phytoplankton $(5-150 \mu \mathrm{m})$. The phytoplankton cells from each plankton net were then passed through a Whatman glass-fibre filter (GF/C). Large phytoplankton were sampled twice to determine the cell density of Pseudo-nitzschia and Nitzschia. For the zooplankton samples, 2001 of seawater was collected at $0.5 \mathrm{~m}$ from the surface and then filtered through a $150 \mu \mathrm{m}$ plankton net. Two zooplankton samples were collected as replicates. The first was filtered through a Whatman glass-fibre filter (GF/C) to extract the DA of the total zooplankton. The second was prepared for DA determination in copepods. Approximately 100 individuals were placed on a Whatman glass-fibre filter $(\mathrm{GF} / \mathrm{C})$ for DA extraction.

\section{Sample preparation and analysis}

Whole tissues of each shellfish and fish specimens were homogenized and then $1 \mathrm{~g}$ samples were added to $4 \mathrm{ml}$ of $50 \%$ methanol before centrifuging at $3500 \mathrm{~g}$ for $30 \mathrm{~min}$. The supernatant was filtered through a Whatman glass-fibre filter (GF/C) to obtain a sample extract for analysis. Extracted samples were then analysed following the ELISA method ${ }^{22}$. All animal samples were measured in $\mathrm{ng} / \mathrm{g}$ tissue (wet weight).

Phytoplankton and zooplankton cells on the Whatman glass-fibre filter (GF/C) were boiled in $2 \mathrm{ml}$ of deionized water for 5-10 $\mathrm{min}$ and then centrifuged $(3500 \mathrm{~g}, 30 \mathrm{~min})$ to obtain the domoic extracts. The extracted samples were then analysed using the ELISA method ${ }^{22}$.

\section{RESULTS}

\section{Phytoplankton density}

Pseudo-nitzschia sp. and Nitzschia sp. were found ubiquitously in the study area with total cell densities ranging from 1300-11 700 cells/l. The highest density was recorded in January 2013 with the lowest in May 2013. Cell densities of Pseudo-nitzschia sp. and Nitzschia sp. ranged between 800 and 9100, and 300 and 2950 cells/1, respectively. One incident of Pseudo-nitzschia sp. red tide was observed in January 2013. Cell densities of Pseudo-nitzschia sp. in both surface and bottom waters between November

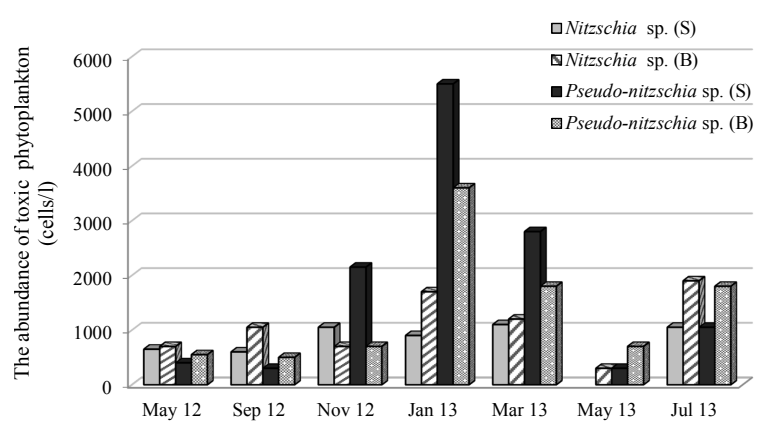

Fig. 2 Changes in cell density of Pseudo-nitzschia sp. and Nitzschia sp. during study period.

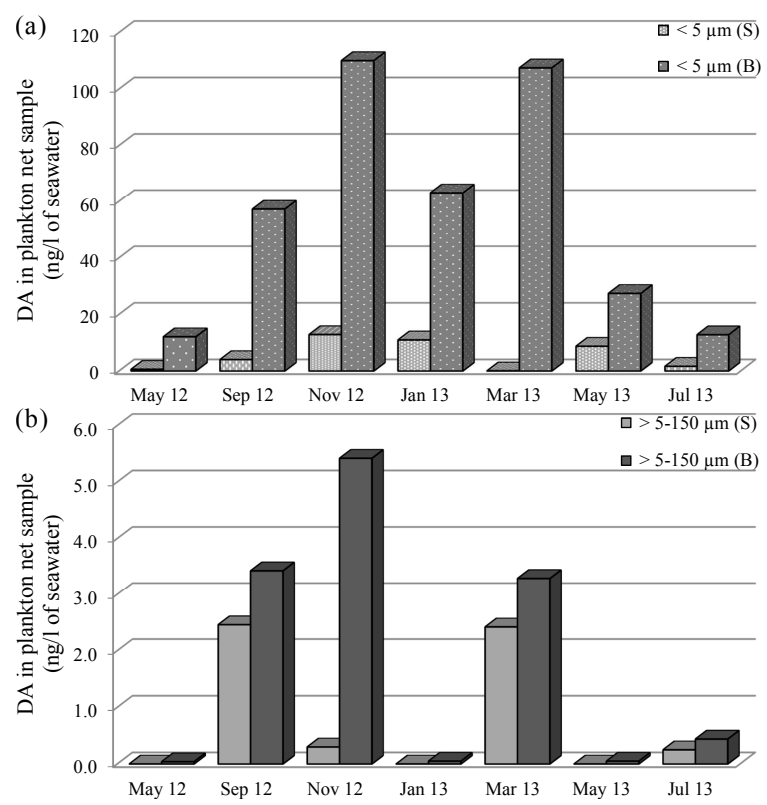

Fig. 3 DA content of (a) small plankton $(<5 \mu \mathrm{m})$ and (b) large plankton (5-150 $\mu \mathrm{m})$ in both surface $(\mathrm{S})$ and bottom waters (B) in set net at Sriracha bay, Chonburi province, Thailand during may 2012-July 2013.

2012 and May 2013 were higher than Nitzschia sp. (Fig. 2).

\section{Domoic acid in phytoplankton}

Domoic acid (DA) was detected throughout the study period in plankton cells both larger and smaller than $5 \mu \mathrm{m}$. DA contents of small plankton in both surface and bottom seawater were more than 10 times higher than large plankton (Fig. 3). The small plankton was mostly phytoplankton, while large plankton consisted of phytoplankton and zooplankton. Some small copepods were also observed in the large plankton fraction.

DA content in large plankton $0.5 \mathrm{~m}$ from the 
sea surface and $0.5 \mathrm{~m}$ above the sediment ranged between not detectable (ND) and $5.42 \mathrm{ng} / \mathrm{l}$. The highest DA contamination in the plankton was recorded in November 2012. DA contents in small phytoplankton at $0.5 \mathrm{~m}$ from the sea surface and $0.5 \mathrm{~m}$ above the sediment ranged between 0.05 and $110.05 \mathrm{ng} / \mathrm{l}$ with the highest contamination also recorded in November 2012 (Fig. 3).

Total DA content in both sizes of plankton at $0.5 \mathrm{~m}$ from the sea surface ranged between 0.58 and $13.15 \mathrm{ng} / \mathrm{l}$, while at $0.5 \mathrm{~m}$ above the sediment values ranged between 12.13 and $115.47 \mathrm{ng} / \mathrm{l}$, with the highest values recorded in November 2012 (Fig. 4).

DA content in large plankton at $0.5 \mathrm{~m}$ from sea surface and $0.5 \mathrm{~m}$ above the sediment ranged between 0 and $5.42 \mathrm{ng} / \mathrm{l}$. The highest contamination of the DA in plankton was found in November 2012. Meanwhile, the DA contents in small phytoplankton at $0.5 \mathrm{~m}$ from sea surface and $0.5 \mathrm{~m}$ above the sediment ranged between 0.05 and $110.05 \mathrm{ng} / \mathrm{l}$, which was also reached the highest contamination in November 2012 (Fig. 3).

The total DA content in both size of plankton at $0.5 \mathrm{~m}$ from sea surface ranged between 0.58 and $13.15 \mathrm{ng} / \mathrm{l}$ while at the $0.5 \mathrm{~m}$ above the sediment ranged between 12.13 and $115.47 \mathrm{ng} / \mathrm{l}$, which was the highest in November 2012 (Fig. 4).
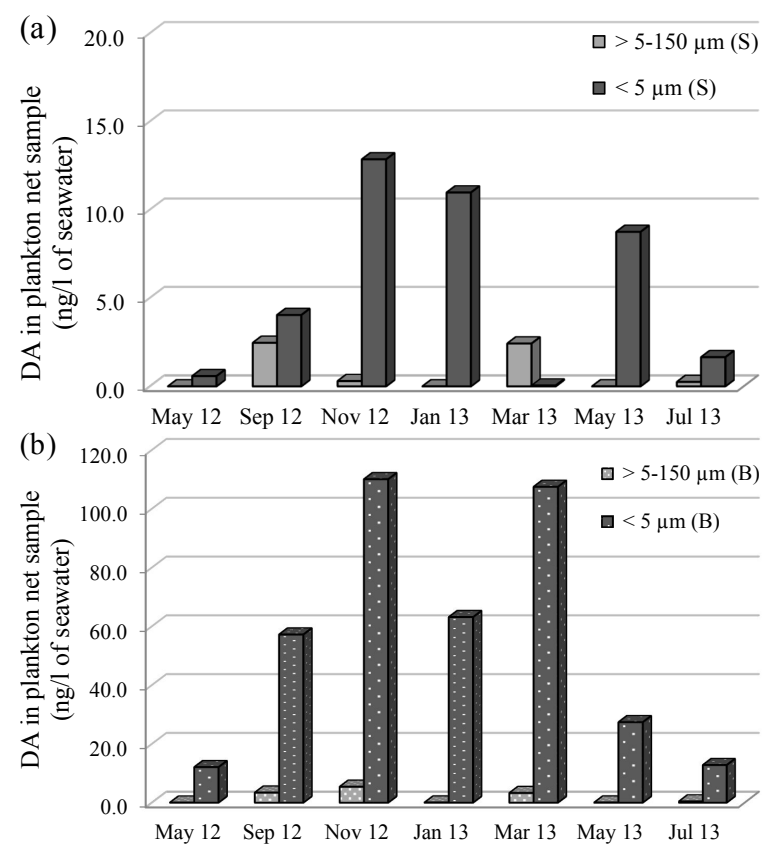

Fig. 4 Total DA content of plankton at surface (a) and bottom water (b) in set net at Sriracha bay, Chonburi province, Thailand during May 2012-July 2013.

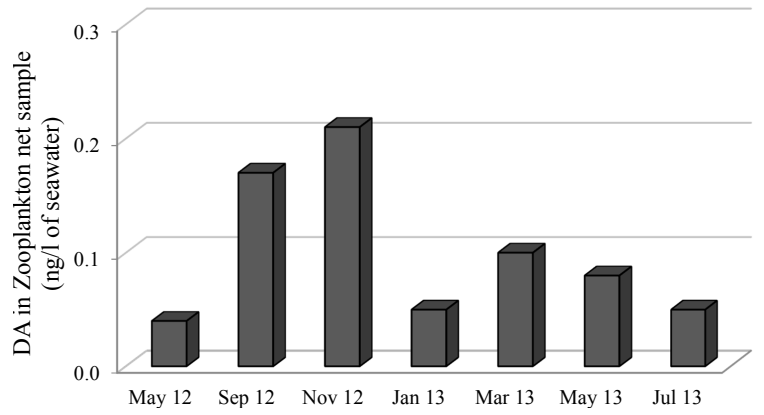

Fig. 5 DA content in zooplankton in set net at Sriracha bay, Chonburi province, Thailand during May 2012-July 2013.

\section{Domoic acid in zooplankton}

DA accumulated in zooplankton ranged between 0.04 and $0.21 \mathrm{ng} / \mathrm{l}$ with the highest value in November 2012 (Fig. 5), whereas DA content accumulated in copepods $(>150 \mu \mathrm{m})$ in May, September, November 2012, and January 2013 was ND, 0.05, 0.11 , and ND ng/cells, respectively. The highest DA content in zooplankton was recorded in November 2012. Results demonstrated that DA contents in zooplankton and copepods corresponded to the amount of DA in phytoplankton that caused DA accumulation in zooplankton.

Seasonal comparisons indicated that average amounts of DA in zooplankton during the wet season $(0.14 \mathrm{ng} / \mathrm{l})$ were higher than during the dry season $(0.07 \mathrm{ng} / \mathrm{l})$. DA content in copepods during the wet season was also higher than during the dry season, corresponding to the DA content in phytoplankton that caused DA in zooplankton as the first consumer transfer into aquatic animals.

\section{Domoic acid in shellfish}

DA contents in $P$ viridis, C. lugubris, and $P$. fucata ranged between 213.56 and 454.24, 171.39 and 370.53 , and 117.06 and $282.14 \mathrm{ng} / \mathrm{g}$ wet weight, respectively (Fig. 6). The highest values of DA in $P$. viridis and $C$. lugubris were recorded in November 2012 and in March 2012 for P. fucata. Average DA content throughout the study period for $P$. viridis was $341 \pm 82 \mathrm{ng} / \mathrm{g}$ wet weight, with $C$. lugubris and $P$. fucata showing $239 \pm 72$ and $176 \pm 54 \mathrm{ng} / \mathrm{g}$ wet weight, respectively. Average DA content in C. lugubris during the wet season $(305 \pm 59 \mathrm{ng} / \mathrm{g}$ wet weight) were markedly higher than during the dry season (189 $\pm 14 \mathrm{ng} / \mathrm{g}$ wet weight), corresponding to the DA content in the phytoplankton. 


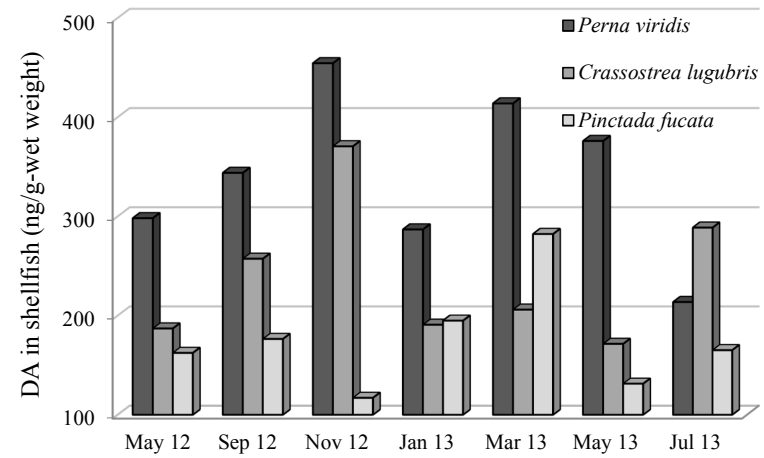

Fig. 6 DA contents in shellfish in set net at Sriracha bay, Chonburi province, Thailand during May 2012-July 2013.

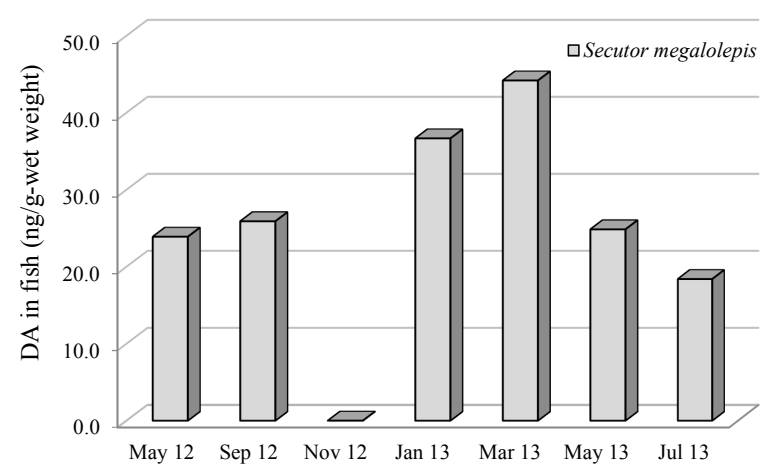

Fig. 7 DA content in S. megalolepis collected from set net in Sriracha bay, Chonburi province, Thailand during May 2012-July 2013.

\section{Domoic acid in fish}

This study represented the first documentation of DA in Thai fish. S. megalolepis is the most common fish in Sriracha bay, Chonburi province. DA content in S. megalolepis ranged between 0 and $44.18 \mathrm{ng} / \mathrm{g}$ wet weight, with the highest value recorded in March 2013 and the lowest in November 2013. Average DA content in S. megalolepis during the wet season was $15 \pm 13 \mathrm{ng} / \mathrm{g}$ wet weight and $32.4 \pm 9.8 \mathrm{ng} / \mathrm{g}$ wet weight during the dry season (Fig. 7).

\section{Domoic acid contamination in marine organisms}

The average DA contamination in phytoplankton, zooplankton, shellfish, and fish is shown in Table 1 for all organisms throughout the study period, ranging between 144.89 and $2877.80 \mathrm{ng} / \mathrm{g}$ dry weight. DA contamination during the wet season (1926.67 ng/g dry weight) was higher than during the dry season (450.00 ng/g dry weight) for zoo-
Table 1 The average DA content (ng/g dry weight) in zooplankton, shellfish, and fish in set net in Sriracha bay, Chonburi province.

\begin{tabular}{lcrcc}
\hline \multirow{2}{*}{ Season } & \multicolumn{4}{c}{ DA content (ng/g dry weight) } \\
\cline { 2 - 5 } & Phytoplankton & Zooplankton & Shellfish & Fish \\
\hline Annual & 2877.80 & 1121.21 & 1258.65 & 144.89 \\
Dry & 2583.13 & 450.00 & 1208.30 & 110.75 \\
Wet & 3270.69 & 1926.67 & 1325.75 & 163.75 \\
\hline
\end{tabular}

plankton.

\section{DISCUSSION}

The cell density of Pseudo-nitzschia sp. in both surface and bottom waters was generally higher than Nitzschia sp. This implied that DA contamination was mainly derived from Pseudo-nitzschia sp. On the contrary, Romero et al recognized $N$. navisvaringica as the main species of phytoplankton producing more DA than Pseudo-nitzschia sp. in the Philippines, Vietnam, Japan, and Thailand ${ }^{23}$. Our results also demonstrated that DA contamination levels in seawater do not depend only on the density of phytoplankton that have the potential to produce toxins. Many factors contribute to DA levels including the phytoplankton species, growth phase, and environmental factors ${ }^{24,25}$. Previous studies reported four Thai species of Pseudo-nitzschia that can produce DA as follows: Pseudo-nitzschia cuspidate and $P$. delicatissima widely distributed around Phuket island ${ }^{26}$, P. pseudodelicatissima found around Chang and Phuket islands, and P. pungens found around Chang, Kram, Ra-Phra Thong and Surin islands, Samut Sakhon and Samut Songkhram provinces ${ }^{26}$. Zabaglo et al also reported that DA originated from Pseudo-nitzschia and Nitzschia ${ }^{1}$. We found that $P$. pungens was the main DA producing species. Yoosamran et al also stated that Pseudonitzschia was the dominant species of phytoplankton in Sriracha bay during October ${ }^{27}$, while Romero et al recorded $N$. navis-varingica as producing DA around Chanthaburi, Chonburi and Bangkok waters $^{23}$. Fortunately, cell densities of these two phytoplankton species (1300-11700 cells/l) were lower than the critical density required to impact on human health through contamination in the food web, estimated to be about $5 \times 10^{4}$ cells/ 1 of Pseudonitzschia australis in California. This density allows mussels and fish meat to reach the average toxic level that impacts on human health ${ }^{9}$.

Most previous DA studies focused on phytoplankton larger than $20 \mu \mathrm{m}^{9,28}$. Dao et al sug- 
gested that the width of the Pseudo-nitzschia cell was narrow enough to pass through a $20 \mu \mathrm{m}$ mesh plankton net ${ }^{28}$. Yotying reported that DA can be detected in phytoplankton both larger and smaller than $20 \mu \mathrm{m}^{29}$. Our results indicated that small plankton $(<5 \mu \mathrm{m})$ amounts were more than 10 times higher than large plankton $(5-150 \mu \mathrm{m})$ in both surface and bottom seawater. This result could be due to the shape of Pseudo-nitzschia spp. and Nitzschia spp. as rice-shaped with 76.4-102.5 $\mu \mathrm{m}$ length and 2.9-4.0 $\mu \mathrm{m}$ width ${ }^{30}$. Furthermore, Tammilehto et al determined that $P$. delicatissima measured only $1.9 \pm 0.01 \mu \mathrm{m}$ in width ${ }^{31}$. Considering the cell width, large plankton could pass through the nets to mix with smaller ones and this might result in high DA content in smaller plankton $(<$ $5 \mu \mathrm{m})$. Our results indicated that DA content in large plankton $(5-150 \mu \mathrm{m})$ was only $4 \%$ of that in small plankton $(<5 \mu \mathrm{m})$. Hence DA contamination in marine organisms around the set nets in Sriracha bay, Chonburi province was mostly from small plankton $(<5 \mu \mathrm{m})$.

Our results indicated that DA content in plankton $0.5 \mathrm{~m}$ above the sediment (28.78 $\mathrm{ng} / \mathrm{l}$ ) was higher than at the sea surface (3.16 $\mathrm{ng} / \mathrm{l}$ ) since the phytoplankton that produced DA belonged to diatoms Pseudo-nitzschia sp. and Nitzschia sp. Diatoms are more abundant at the water bottom as the silicate inside their cells makes them sink. Statistical analysis also showed a significant $(p<0.05)$ difference between surface and bottom water content of DA in small plankton $(<5 \mu \mathrm{m})$. However, James et al found no relationship between the density of Pseudo-nitzschia and DA content in shellfish in Ireland $^{32}$. Busse et al noted that DA content in phytoplankton (maximum $2.33 \mu \mathrm{g} / \mathrm{l}$ ) had no relationship with phytoplankton density (maximum 70500 cell$\mathrm{s} / 1)^{8}$. Furthermore, Liefer et al also determined that DA content in the Gulf of Mexico had no correlation with the density of Pseudo-nitzschia cells ${ }^{33}$. Diverse environmental and oceanographic conditions could stimulate DA production of phytoplankton and affect growth stages. Dao et al described DA production of Pseudo-nitzschia as changing greatly during the life cycle ${ }^{28}$. This suggestion concurred with Bates and Richard, who stated that DA content in Pseudo-nitzschia multiseries was very high in the stationary phase ${ }^{34}$.

Total DA content in both sizes of plankton at $0.5 \mathrm{~m}$ from the sea surface was still very low (12.13$115.47 \mathrm{ng} / \mathrm{l}$ ) compared to Vale and Sampayo, who recorded maximum DA levels in phytoplankton samples greater than $700 \mathrm{ng} / \mathrm{l}^{35}$. However, DA content from the fraction larger than $20 \mu \mathrm{m}(12 \mathrm{ng} / \mathrm{l})$ of this study was higher than in Nha Phu Bay, Vietnam ${ }^{28}$. Yotying found that total DA content in phytoplankton at Kham Yai island, Chonburi province, ranged between 0.49 and $2.04 \mathrm{ng} / \mathrm{1}^{29}$, which was low compared to our results.

DA content during the wet season (17.57 ng/l) was higher than the dry season (14.77 ng/1). This might be caused by increased nutrients from water run-off stimulating phytoplankton growth. Trainer et al suggested that the bloom of Pseudo-nitzschia occurred after nutrient increase through heavy rain ${ }^{36}$. Total DA content in the water column during the phytoplankton bloom was measured at $2.33 \mu \mathrm{g} / 1^{9}$.

This study presents the first investigation of DA accumulation in zooplankton from Thai waters. Previous studies concentrated on phytoplankton and shellfish only ${ }^{19,29}$. Our results revealed that copepods and other zooplankton accumulate DA by consuming DA-producing phytoplankton and concurred with Tammilehto et al, who found that three Calanus species (Calanus glacialis, Calanus finmarchicus, and Calanus hyperboreus) accumulated DA with potential to vector for higher DA trophic levels in the Arctic marine ecosystem ${ }^{31}$. They also determined that $C$. finmarchicus and C. hyperboreus stopped grazing after feeding on Pseudo-nitzschia seriata for 6-12 h and suggested that copepods may be affected by physiological incapacitation caused by ingesting DA. However, DA ingested by the copepod Acartia clausi did not affect mortality, feeding behaviour, egg production, or egg hatching ${ }^{37}$. They also suggested that copepods could absorb 5\% of the total DA ingested. The quantity of toxins eliminated daily by copepods was $64 \%$, so copepods accumulated DA in their tissues. Leandro et al found that copepods (C. finmarchicus) showed ability as a DA carrier with transfer to the next consumer of upper trophic level ${ }^{38}$.

Our results showed that DA content in $P$ viridis was greater than in C. lugubris and P. fucata, probably because of the different filtration rates of each mussel. This agreed with Musig et al, who showed that the filtration rate of $P$ viridis was $1.96-2.771 / \mathrm{h}$ while Crassostrea iredalei recorded 0.03-1.13 1/ $\mathrm{h}^{39}$. Comeau et al found that clearance rates of $M$. edulis and Crassostrea virginica at $9^{\circ} \mathrm{C}$ were $1.82-2.90$ and $0.05-1.21 \mathrm{l} / \mathrm{h}$, respectively ${ }^{40}$. Mafra et al found that mussels (M. edulis) could accumulate 8-17 times higher DA concentration (max. $460 \mu \mathrm{g} / \mathrm{g}$ ) than oysters $(C$. virginica) (max. $78.6 \mu \mathrm{g} / \mathrm{g}){ }^{41}$. They suggested that DA content in mussels depended on body size, exposure time and DA removal rates. Normally, 
the DA depuration time of shellfish varies widely, ranging from a few days to several months ${ }^{37}$. Mafra et al found that mussels (M. edulis) fed on both long and short-celled Pseudo-nitzschia multiseries from a mixed suspension, whereas oysters (C. virginica) preferentially rejected long cells $(>70 \mu \mathrm{m})$ as pseudofaeces ${ }^{42}$. However, our overall results indicated that DA contents in three shellfish $(0.17-$ $0.45 \mu \mathrm{g} / \mathrm{g}$ ) were lower than the regulation level $(20 \mu \mathrm{g} / \mathrm{g})$, while DA content in the oyster Spondylus versicolor in Thai waters ranged between 1.07 and $1.75 \mu \mathrm{g} / \mathrm{g}^{19,29}$. Dao et al reported that DA content of Spondylus in Vietnam was high at $146.8 \mu \mathrm{g} / \mathrm{g}^{28}$. This indicated that $S$. versicolor accumulated more DA than the three shellfish in our study since its habitat was bottom water. Hence DA content in bottom water plankton was higher than at the surface. In our study, DA content in P. viridis (213.56$454.24 \mathrm{ng} / \mathrm{g}$ wet weight) was high compared to P. viridis in Philippines water $(60 \mathrm{ng} / \mathrm{g})^{19}$. However, densities of Pseudo-nitzschia sp. and Nitzschia sp. in our study area were low (1300-11700 cells/l) compared with the critical density (dangerous levels in a food chain) at $5 \times 10^{4}$ cells $/ 1$ of $P$. australis ${ }^{9}$. Our results also indicated that DA content in shellfish during the wet season was markedly higher than during the dry season. This occurred because DA content of Pseudo-nitzschia sp. and Nitzschia sp. exhibited seasonal variation as DA content in the water column during wet season was higher than during the dry season. This result conformed with Dao et al, who reported that DA level in Spondylus versicolor increased when DA levels in plankton samples in Nha Phu Bay, Khanh Hoa, Vietnam increased ${ }^{28}$. Yotying investigated DA content in S. versicolor at Kham Yai island, Chonburi province which relates to DA in phytoplankton ${ }^{29}$. Bates et al and Huyen et al also stated that DA content in M. edulis was related to DA in phytoplankton in Canadian and Vietnamese waters, respectively ${ }^{43,44}$. Thus DA can accumulate in shellfish by a food-web transfer with seasonal variation.

DA contamination levels in fish from Thai waters (0-44.18 ng/g wet weight) were low compared to other global regions. Previous studies suggested that contamination of DA in fish was high compared to our study. Vale and Sampayo reported that maximum DA content in sardines was $74200 \mathrm{ng} / \mathrm{g}^{35}$, while Lefebvre et al found that DA content in anchovies and sardines was $200-2200 \mathrm{ng} / \mathrm{g}^{8}$. However, our results were similar to Liefer et al, who found that DA of Gulf kingfish, striped anchovy and white mullet in the Northern Gulf of Mexico were
53, 23, and $44 \mathrm{ng} / \mathrm{g}$, respectively ${ }^{33}$. DA production of phytoplankton can be transferred in trophic levels and Bates and Trainer discovered that bivalves were the major carriers in transferring DA through food chains, together with other aquatic organisms as shrimp, crab, fish, and benthos ${ }^{7}$.

Our results demonstrated that average DA content in zooplankton and shellfish increased or reduced depending on DA content in phytoplankton in the water column. However, DA content in fish had no relation with the density of DA producing phytoplankton. This may be because DA depuration by fish is normally fairly rapid. Generally, DA content in planktivorous fish was consistent with total DA in Pseudo-nitzschia population in the water column. Hence fish are not safe to eat during phytoplankton blooms or red tide incidents. Many phytoplankton-feeding fishes can accumulate DA at high levels during the Pseudo-nitzschia bloom. DA transfer from producer to consumer is different from energy or mass transfer. Energy transfer to upper trophic levels is passed at only about $10-20 \%$ with $80-90 \%$ energy loss in the form of metabolism. Jeawkok calculated the percentage of carbon transfer from phytoplankton to zooplankton at $18 \%{ }^{45}$. For DA transfer, this mechanism process is called biomagnification and various substances can be transferred to creatures from eating food, resulting in a higher concentration compared to the source ${ }^{18}$. DA is a toxic substance that is not used to generate energy for cell growth; hence accumulation of this toxin in the body of the organism increases with increasing trophic levels. The total consumption of DA content by phytoplankton and zooplankton can be calculated using the data set of water content and carbon transfer. The calculated total DA consumption of herbivorous zooplankton and zooplankton feeders based on carbon transfer at $18 \%$ (Table 2). Average annual consumptions of DA content by herbivorous zooplankton and zoo-

Table 2 The average of DA content (ng/g dry weight) in phytoplankton and zooplankton and the total DA consumption of herbivorous zooplankton and zooplankton feeders based on carbon transfer at $18 \%$.

\begin{tabular}{lcrlcr}
\hline Season & \multicolumn{2}{c}{ DA content } & & \multicolumn{2}{c}{ Total DA consumption } \\
\cline { 2 - 3 } \cline { 2 - 3 } & Phytoplank & Zooplank & & Herbivorous & Feeders \\
\hline Annual & 2877.8 & 1121.2 & & 15674.3 & 6106.8 \\
Dry & 2583.1 & 450.0 & & 14069.3 & 2451.0 \\
Wet & 3270.7 & 1926.7 & & 17814.2 & 10493.9 \\
\hline
\end{tabular}


Table 3 The percentage of DA transfer between marine organisms in set net, Sriracha bay, Chonburi province.

\begin{tabular}{lccc}
\hline Season & \multicolumn{3}{c}{ DA transfer (\%) } \\
\cline { 2 - 4 } & Phytopt-Zoopt & Phytopt-Shellfish & Zoopt-Fish \\
\hline Annual & 7.15 & 8.03 & 2.37 \\
Dry & 3.20 & 8.59 & 4.52 \\
Wet & 10.82 & 7.44 & 1.56 \\
\hline
\end{tabular}

plankton feeders were 15674.3 and 6106.8 (ng/g dry weight), respectively. Thus to maintain the average annual content of DA in the body of herbivorous zooplankton (1121.2 ng/g dry weight) and zooplankton feeders (144.9 ng/g dry weight), they have to consume foods containing DA content at 15674.3 and $6106.8 \mathrm{ng} / \mathrm{g}$ dry weight, respectively.

Annual efficiency of DA transfer from phytoplankton to zooplankton and shellfish based on the calculated average annual consumption of DA content were $7 \%$ and $8 \%$, respectively (Table 3 ), with annual efficiency of DA transfer from zooplankton to fish at $2 \%$. Results demonstrated that although the average content of DA throughout the year in zooplankton, shellfish, and fish were calculated at $42 \%, 44 \%$, and $5 \%$ compared to the content in phytoplankton, respectively, DA transfer between trophic levels was low. In addition, DA transfers from phytoplankton to zooplankton and shellfish during the dry season were $3 \%$ and $9 \%$, respectively, with $5 \%$ from zooplankton to fish. In the wet season, DA transfer from phytoplankton to zooplankton was high (11\%), while transfer from zooplankton to fish was only $2 \%$. Overall results demonstrated that DA transfers from phytoplankton to zooplankton, shellfish, and fish contradicted the theory of biomagnification considering the total consumption of DA content to remaining DA content in the bodies of marine organisms. The contamination of DA in marine organism bodies during the wet season was significantly higher than during the dry season.

Acknowledgements: This work was supported by the Higher Education Research Promotion and National Research University Project of Thailand, Office of the Higher Education Commission. This study was also partial supported funding from National Research Council of Thailand and JSPS-NRCT Core to Core Programme: Harmful Algal Blooms.

\section{REFERENCES}

1. Zabaglo K, Chrapusta E, Bober B, Kaminski A, Adamski M, Bialczyk J (2016) Environmental roles and biological activity of domoic acid: a review. Algal Res 13, 94-101.

2. Morabito S, Silvestro S, Faggio C (2017) How the marine biotoxins affect human health. Nat Prod Res (in press).

3. Doucette G, Maneiro I, Riveiro I, Svensen C (2006) Phycotoxin pathways in aquatic food webs: transfer, accumulation and degradation. In: Granéli E, Turner JT (eds) Ecology of Harmful Algae, Ecological Studies (Analysis and Synthesis) vol 189, Springer, Berlin, Heidelberg, pp 283-95.

4. Walter JA, Leek DM, Falk M (1992) NMR study of the protonation of domoic acid. Can J Chem 70, 1156-61.

5. Clayden J, Read B, Hebditch KR (2005) Chemistry of domoic acid, isodomoic acids, and their analogues. Tetrahedron 61, 5713-24.

6. Perl TM, Bédard L, Kosatsky T, Hockin JC, Todd E, Remis RS (1990) An outbreak of toxic encephalopathy caused by eating mussels contaminated with domoic acid. New Engl J Med 322, 1775-80.

7. Bates SS, Trainer VL (2006) The ecology of harmful diatoms. In: Granéli E, Turner JT (eds) Ecology of Harmful Algae, Ecological Studies (Analysis and Synthesis) vol 189, Springer, Berlin, Heidelberg, pp 81-93.

8. Lefebvre KA, Silver MW, Coale SL, Tjeerdema RS (2002) Domoic acid in planktivorous fish in relation to toxic Pseudo-nitzschia cell densities. Mar Biol 140, 625-31.

9. Busse LB, Venrick EL, Antrobus R, Miller PE, Vigilant V, Silver MW, Mengelt C, Mydlarz L, et al (2006) Domoic acid in phytoplankton and fish in San Diego, CA, USA. Harmful Algae 5, 91-101.

10. Torre A, Trischitta F, Faggio C (2013) Effect of $\mathrm{CdCl}_{2}$ on regulatory volume decrease (RVD) in Mytilus galloprovincialis digestive cells. Toxicol In Vitro 27, 1260-6.

11. Pagano M, Porcino C, Briglia M, Fiorino E, Vazzana M, Silvestro S, Faggio C (2017) The influence of exposure of cadmium chloride and zinc chloride on haemolymph and digestive gland cells from Mytilus galloprovincialis. Int J Environ Res 11, 207-16.

12. Bartoskova M, Dobsikova R, Stancova V, Zivna D, Blahova J, Marsalek P, Zelníckova L, Bartos M, et al (2013) Evaluation of ibuprofen toxicity for zebrafish (Danio rerio) targeting on selected biomarkers of oxidative stress. Neuroendocrinol Lett 34(Suppl 2), 102-8.

13. Chromcova L, Blahova J, Zivna D, Plhalova L, Casuscelli di Tocco F, Divisova L, Prokes M, Faggio C, et al (2015) NeemAzal T/S-toxicity to early-life stages of common carp (Cyprinus carpio L.). Vet Med 60, 23-30.

14. Faggio C, Pagano M, Alampi R, Vazzana I, Felice MR (2016) Cytotoxicity, haemolymphatic parameters, and oxidative stress following exposure to sub- 
lethal concentrations of quaternium-15 in Mytilus galloprovincialis. Aquat Toxicol 180, 258-65.

15. Savorelli F, Manfra L, Croppo M, Tornambè A, Palazzi D, Canepa S, Trentini PL, Cicero AM, et al (2017) Fitness evaluation of Ruditapes philippinarum exposed to Ni. Biol Trace Elem Res 177, 384-93.

16. Fazio F, Piccione G, Tribulato K, Ferrantelli V, Giangrosso G, Arfuso F, Faggio C (2014) Bioaccumulation of heavy metals in blood and tissue of striped mullet in two Italian lakes. J Aquat Anim Health 26, 278-84.

17. Burgos-Aceves MA, Faggio C (2017) An approach to the study of the immunity functions of bivalve haemocytes: physiology and molecular aspects. Fish Shellfish Immunol 67, 513-7.

18. Gray JS (2002) Biomagnification in marine systems: the perspective of an ecologist. Mar Pollut Bull 45, 46-52.

19. Takata Y, Sato S, Ha DV, Montojo UM, Lirdwitayaprasit T, Kamolsiripichaiporn S, Kotaki Y, Fukuyo Y, et al (2009) Occurrence of domoic acid in tropical bivalves. Fish Sci 75, 473-80.

20. Anderson DM, Andersen P, Bricelj VM, Cullen JJ, Rensel JE (2001) Monitoring and Management Strategies for Harmful Algal Blooms in Coastal Waters, APEC \#201-MR-01.1, Asia Pacific Economic Program, Singapore, and Intergovernmental Oceanographic Commission Technical Series No 59, Paris.

21. McCarron P, Hess P (2006) Tissue distribution and effects of heat treatments on the content of domoic acid in blue mussels, Mytilus edulis. Toxicon 47, 473-9.

22. Dao VH, Takata Y, Sato S, Fukuyo Y, Kodama M (2006) Domoic acid in a bivalve Spondylus cruentus in Nha Trang Bay, Khanh Hoa Province, Vietnam. Coast Mar Sci 30, 130-2.

23. Romero MLJ, Lirdwitayaprasit T, Kotaki Y, Lundholm N, Relox Jr J, Furio EF, Terada R, Yokoyama T, et al (2008) Isolation of ASP toxin-producing Nitzschia from Thailand. Mar Res Indones 33, 225-8.

24. Kotaki Y (2008) Ecobiology of amnesic shellfish toxin producing diatoms. In: Botana LM (ed) Seafood and Freshwater Toxins Pharmacology, Physiology, and Detection, 2nd edn, CRC Press, pp 383-96.

25. Lundholm N, Hansen PJ, Kotaki Y (2004) Effect of pH on growth and domoic acid production by potentially toxic diatoms of the genera Pseudo-nitzschia and Nitzschia. Mar Ecol Progr 273, 1-15.

26. Priisholm K, Moestrup $\varnothing$, Lundholm N (2002) Taxonomic notes on the marine diatom genus Pseudonitzschia in the Andaman sea near the island of Phuket, Thailand, with a description of Pseudonitzschia micropora sp. nov. Diatom Res 17, 153-75.

27. Yoosamran C, Khuntavong A, Rerrmdunri S (2006) Relationships between water qualities and phytoplankton at Sriracha bay, Chonburi province. In: Proceedings of the 44th Kasetsart Univ Annual Conference: Fisheries, Bangkok, pp 511-7.

28. Dao VH, Takata Y, Omura T, Sato S, Fukuyo Y, Ko- dama M (2009) Seasonal variation of domoic acid in a bivalve Spondylus versicolor in association with that in plankton samples in Nha Phu Bay, Khanh Hoa, Vietnam. Fish Sci 75, 507-12.

29. Yotying T (2009) Seasonal variations of domoic acid accumulation in spiny oyster Spondylus cf. versicolor at Kham Yai island, Chonburi province. MSc thesis, Chulalongkorn Univ, Thailand.

30. Kotaki Y, Koike K, Sato S, Ogata T, Fukuyo Y, Kodama M (1999) Confirmation of domoic acid production of Pseudo-nitzschia multiseries isolated from Ofunato Bay, Japan. Toxicon 37, 677-82.

31. Tammilehto A, Nielsen TG, Krock B, Møller EF, Lundholm N (2012) Calanus spp.--vectors for the biotoxin, domoic acid, in the Arctic marine ecosystem? Harmful Algae 20, 165-74.

32. James KJ, Gillman M, Fernández Amandi M, LópezRivera A, Fernández Puente P, Lehane M, Mitrovic S, Furey A (2005) Amnesic shellfish poisoning toxins in bivalve molluscs in Ireland. Toxicon 46, 852-8.

33. Liefer JD, Robertson A, MacIntyre HL, Smith WL, Dorsey CP (2013) Characterization of a toxic Pseudonitzschia spp. bloom in the Northern Gulf of Mexico associated with domoic acid accumulation in fish. Harmful Algae 26, 20-32.

34. Bates SS, Richard J (1996) Domoic acid production and cell division by Pseudo-nitzschia multiseries in relation to a light:dark cycle in silicate-limited chemostat culture. In: Penney RW (ed) Proceedings of the Fifth Canadian Workshop on Harmful Marine Algae, pp 140-3.

35. Vale P, Sampayo MAM (2001) Domoic acid in Portuguese shellfish and fish. Toxicon 39, 893-904.

36. Trainer VL, Adams NG, Bill BD, Stehr CM, Wekell JC, Moeller P, Busman M, Woodruff D (2000) Domoic acid production near California coastal upwelling zones, June 1998. Limnol Oceanogr 45, 1818-33.

37. Maneiro I, Iglesias P, Guisande C, Riveiro I, Barreiro A, Zervoudaki S, Granéli E (2005) Fate of domoic acid ingested by the copepod Acartia clausi. Mar Biol 148, 123-30.

38. Leandro LF, Teegarden GJ, Roth PB, Wang Z, Doucette GJ (2010) The copepod Calanus finmarchicus: a potential vector for trophic transfer of the marine algal biotoxin, domoic acid. J Exp Mar Biol Ecol 382, 88-95.

39. Musig Y, Musig W, Sangrungruang C, Sathianchit S, Intarachart A (2012) The use of bivalve mollusks for the remediation of aquatic environment. Research Report, National Research Council of Thailand, Thailand.

40. Comeau LA, Pernet F, Tremblay R, Bates SS, LeBlanc A (2008) Comparison of eastern oyster (Crassostrea virginica) and blue mussel (Mytilus edulis) filtration rates at low temperatures. Canadian Technical Report of Fisheries and Aquatic Sciences 2810, Department of Fisheries and Oceans, Canada. 
41. Mafra Jr LL, Bricelj VM, Fennel K (2010) Domoic acid uptake and elimination kinetics in oysters and mussels in relation to body size and anatomical distribution of toxin. Aquat Toxicol 100, 17-29.

42. Mafra Jr LL, Bricelj VM, Ouellettea C, Bates SS (2010) Feeding mechanics as the basis for differential uptake of the neurotoxin domoic acid by oysters, Crassostrea virginica, and mussels, Mytilus edulis. Aquat Toxicol 97, 160-71.

43. Bates SS, Bird CJ, de Freitas ASW, Foxall R, Gilgan M, Hanic LA, Johnson GR, McCulloch AW, et al (1989) Pennate diatom Nitzschia pungens as the primary source of domoic acid, a toxin in shellfish from Eastern Prince Edward Island, Canada. Can J Fish Aquat Sci 46, 1203-15.

44. Huyen NTM, Thuoc CV, Ogata T, Sato S, Takata Y, Kodama M, Fukuyo Y (2006) Seasonal variation of paralytic and amnesic shellfish toxicities in bivalves and microalgae in Haiphong area, Vietnam. Coast Mar Sci 30, 111-5.

45. Jeawkok R (2015) Element transfer from aquatic environment to phytoplankton and zooplankton in Bang-Tabun bay, Phetchaburi province. MSc thesis, Kasetsart Univ, Thailand. 